\title{
Influence of Geological Conditions during Peat Accumulation on Trace Element Affinities and Their Behavior during Peat Combustion
}

\author{
S. Kalaitzidis, ${ }^{\dagger}$ K. Christanis, ${ }^{*}{ }^{\dagger}$ A. Georgakopoulos, ${ }^{\ddagger}$ J . L. Fernández-Turiel, ${ }^{\S}$ and \\ S. Papazisimou ${ }^{\dagger}$
}

Department of Geology, University of Patras, GR-26500 Rio, Patras, Greece, Department of Mineral ogy-Petrol ogy-Economic Geology, Aristotle University, GR-54006 Thessal oniki, Greece, and Institute of Earth Sciences "J aume Almera", CSIC, C/ Solé i Sabaris s/ n,

E-08028 Barcelona, Spain

Received March 13, 2002

The Philippi peat, NE Greece, constitutes one of the largest fossil fuel deposits in the Balkans and its potential use for power generation cannot be ruled out in the future. In this study, the concentrations of 43 trace elements (Ag, $\mathrm{As}, \mathrm{Ba}, \mathrm{Be}, \mathrm{Bi}, \mathrm{Cd}, \mathrm{Ce}, \mathrm{Co}, \mathrm{Cr}, \mathrm{Cs}, \mathrm{Cu}, \mathrm{Dy}, \mathrm{Er}, \mathrm{Eu}, \mathrm{Ga}$, $\mathrm{Gd}, \mathrm{Ge}, \mathrm{Hf}, \mathrm{Ho}, \mathrm{La}, \mathrm{Li}, \mathrm{Mo}, \mathrm{Nb}, \mathrm{Nd}, \mathrm{Ni}, \mathrm{Pb}, \mathrm{Pr}, \mathrm{Rb}, \mathrm{Sb}, \mathrm{Sc}, \mathrm{Sm}, \mathrm{Sn}, \mathrm{Sr}, \mathrm{Ta}, \mathrm{Tb}, \mathrm{Th}, \mathrm{U}, \mathrm{V}, \mathrm{W}, \mathrm{Y}$, $\mathrm{Yb}, \mathrm{Zn}$, and $\mathrm{Zr}$ ) in the $550^{\circ} \mathrm{C}$ peat ashes are determined and related to the concentrations in the bulk peat, to evaluate the behavior of each element during combustion. Mineralogical analysis of the chemically oxidized peat samples revealed that clay minerals, feldspars, quartz, gypsum, and calcite are the dominant mineral phases. The behavior of the trace elements during combustion depends significantly on this mineral composition that, in turn, depends on the depositional conditions during peat accumulation.

\section{Introduction}

In the past decades, many countries have revised their energy policies, especially those concerning the fossil fuel exploitation for power generation, toward a more environmental friendly approach. Therefore, a lot of effort is being currently made to predict and determine the environmental impacts from coal utilization by studying the behavior of certain trace el ements and their potentially hazardous effects during coal combustion. ${ }^{1-9}$

Many studies on the geochemical features of the trace elements contained in coal have been conducted in order to evaluate the environmental importance of their behavior during combustion. ${ }^{10-12}$ According to Swaine ${ }^{6}$ the trace elements with significant environmental inter-

* Corresponding author. Tel.: (++30)-610997568. Fax: (++30)610991900. E-mail: christan@upatras.gr.

† Department of Geology.

₹ Department of Mineralogy-Petrology-E conomic Geology.

$\S$ Institute of Earth Sciences "J aume Almera".

(1) Finkelman, R. B. Fuel Process. Technol. 1994, 39, 21-34.

(2) Querol, X.; Fernández-Turiel, J . L.; López-Soler, A. Fuel 1995

74/3, 331-343.

(3) Spears, D. A.; Zheng, Y. Int. J . Coal Geol. 1999, 38, 161-179.

(4) Finkelman, R. B.; Gross P. M. K. Int. J. Coal Geol. 1999, 40, 91-101.

(5) Kizilshtein, L. Ya.; Kholodkov, Yu. I. Int. J . Coal Geol. 1999, 40, 189-197.

(6) Swaine, D. J . Fuel Process. Technol. 2000, 65-66, 21-33.

(7) Llorens, 」 . F.; Fernández-Turiel, J . L.; Querol, X. Environ. Geol 2001, 40 (4/5), 409-416.

(8) Vassilev, S. V.; Eskenazy, G. M.; Vassileva, C. G. Fuel Process. Technol. 2001, 72, 103-129.

(9) Yan, R.; Gauthier, D.; Flamant, G. Fuel 2001, 80, 2217-2226.

(10) Clarke, L. B.; Sloss, L. L. TraceElements-E missions from Coal Combustion and Gasification; IEA Coal Research 49; IEA Coal Research: London, 1992; 111 pp. est are $\mathrm{As}, \mathrm{Cd}, \mathrm{Cr}, \mathrm{Hg}, \mathrm{Pb}$, Se, $\mathrm{B}, \mathrm{Cl}, \mathrm{F}, \mathrm{Mn}, \mathrm{Mo}, \mathrm{Ni}, \mathrm{Be}$, $\mathrm{Cu}, \mathrm{P}, \mathrm{Th}, \mathrm{U}, \mathrm{V}, \mathrm{Zn}, \mathrm{Ba}, \mathrm{Co}, \mathrm{I}, \mathrm{Ra}, \mathrm{Sb}, \mathrm{Sn}$, and TI. Moreover, $\mathrm{Sb}, \mathrm{As}, \mathrm{Be}, \mathrm{Cd}, \mathrm{Cl}, \mathrm{Cr}, \mathrm{Co}, \mathrm{F}, \mathrm{Pb}, \mathrm{Hg}, \mathrm{Mn}, \mathrm{Ni}$, $\mathrm{Se}$, and $\mathrm{U}$ are considered as hazardous air pollutant elements. ${ }^{1}$

The mobility of trace elements during combustion (i.e., partitioning, volatilization, and condensation) depends on the concentration and the affinity of each element, the chemical reactions during combustion, which are directly controlled by the physicochemical features of the contained minerals and organic compounds, and finally on the combustion technique. Except for the latter, these factors vary strongly from one coal deposit to another, as well as within each deposit.

The majority of exploited coals worldwide is of high rank and, consequently, has high calorific values. However, due to the lack of domestic high-rank coals in Greece, the power generation is based mainly on lignite. Although the rank significantly contributes to the geochemical features of the coal, the most essential parameter concerning coal quality is the local environmental conditions during and after peat accumulation. Geochemical studies of different coal deposits are keys in the effort to understand the mode of occurrence of the trace elements, as well as their behavior during combustion. In this context, the study of peat as a coal precursor can contribute to this effort. Although peat

(11) Swaine, D. J . In: Environmental Aspects of Trace Elements in Coal; Swaine, D. J ., Goodarzi, F., Eds.; Kluwer Academic Publishers: Dordrecht, The Netherlands, 1995; pp 5-23.

(12) Meij, R. In: Environmental Aspects of Trace Elements in Coal; Swaine, D. J ., Goodarzi, F., Eds.; Kluwer Academic Publ.: Dordrecht, The Netherlands 1995; pp 111-127. 


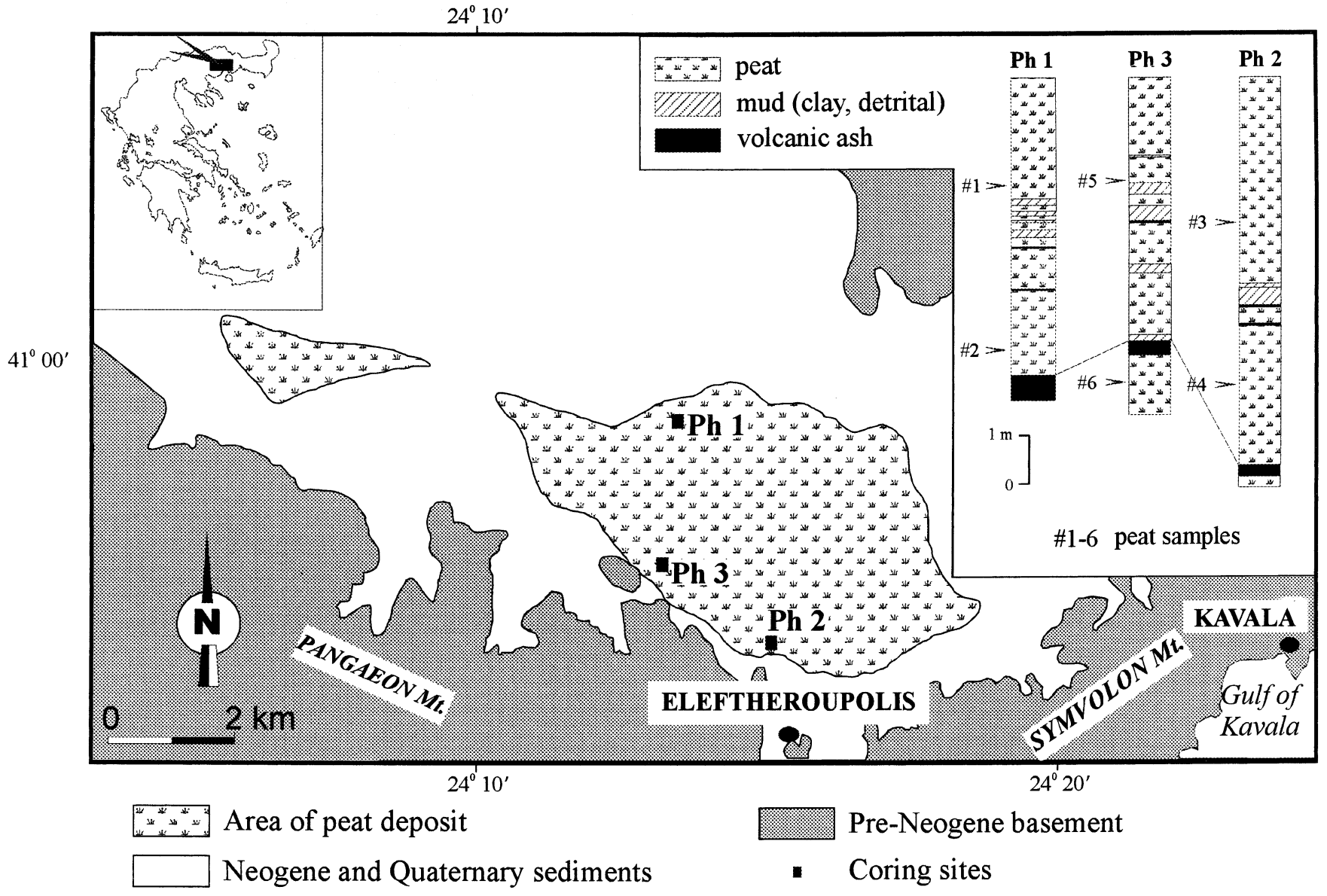

Figure 1. Simplified map of the Philippi peatland.

is not widely used for power generation, some countries, such as Finland and I reland, cover a significant portion of their domestic energy demand by exploiting peat. ${ }^{13}$

In recent years, a number of studies have focused on the trace element contents in the Greek lignites (e.g., refs 14-16), as well as on the behavior of trace el ements during combustion. ${ }^{17-21}$ Previous studies on Greek peat are restricted to some geochemical and mineralogical features of the Philippi peat.22-24

The current study is complementary to a previous one, ${ }^{22}$ in which the distribution and the mode of occurrence of the trace elements on bulk peat were defined. The aim of the present study is to determine the trace

(13) Schilstra, A. J . E col. E con. 2001, 39, 285-293.

(14) Foscolos, A. E.; Goodarzi, F.; Koukouzas, C. N.; Hatziyannis, G. Chem. Geol. 1989, 76, 107-130.

(15) Filippidis, A.; Georgakopoulos, A.; Kassoli-Fournaraki, A.; Misaelidis, P.; Yiakkoupis, P.; Broussoulis, J . Int. J . Coal Geol. 1996, 29, 219-234.

(16) Georgakopoulos, A. Energy Sources 2001, 23, 143-156.

(17) Filippidis, A.; Georgakopoulos, A. Fue 1992, 71/4, 373-376.

(18) Georgakopoulos, A.; Filippidis, A.; Kassoli-F ournaraki, A. Fuel 1994, 73, 1802-1804.

(19) Georgakopoulos, A.; Filippidis, A.; Kassoli-Fournaraki, A.; I ordanidis, A.; Fernández-Turiel, J . L.; Llorens, J . F.; Gimeno, D. Energy Sources 2002, 24, 83-91. 423.

(20) Sakorafa, V.; Michailidis, K.; Burragato, F. Fue 1996, 75, 419

(21) I ordanidis, A.; Georgakopoulos, A.; Filippidis, A.; KassoliFournalaki, A. Int. J . Environ. Anal. Chem. 2001, 79/2, 133-141.

(22) Christanis, K.; Georgakopoulos, A.; Fernández-Turiel, J. L.; Bouzinos, A. Int. J . Coal Geol. 1998, 36, 295-313.

(23) Kalaitzidis, S.; Christanis, K. In Sustaining our Peatlands: Rochefort, L., Daigle, J . Y., Eds.; Proceedings of the 11th International Peat Congress; 2000; Vol. 2, pp 593-603.

81.

(24) Kalaitzidis, S.; Christanis, K. Energy Sources 2002, 24, 69- element contents in the ashes of the same peat samples and to compare them with the results on the bulk peat samples in order to assess the behavior of the trace elements during combustion. Moreover, mineralogical data are evaluated in the current study on peat wetashes in a way that the affinity of the trace elements can be clarified.

\section{Geological Setting}

The Philippi peatland is located in the southern part of the intermontane basin of Drama in eastern Macedonia, northern Greece (Figure 1). The peatland occupies an area of $55 \mathrm{~km}^{2}$ and was drained between 1931 and 1944 for agricultural purposes. Drainage and intense cultivation resulted in peat oxidation and loss of the 3-4 m thick toplayer. ${ }^{25}$ The whole peat sequence in the Philippi area reaches a maximum thickness of $190 \mathrm{~m}$, being the thickest known peatland in the world. ${ }^{25}$ The gross cal orific value of peat ranges between 3160 and $4880 \mathrm{kcal} / \mathrm{kg}$ on dry basis and the proven reserves amount to a total of 4,300 million $\mathrm{m}^{3}$ bulk peat or almost one billion tons dry peat. ${ }^{26}$ Since the constantly increasing energy demand of Greece is covered by lignite up to $70 \%,{ }^{27}$ the Philippi peat deposit constitutes a potential resource for power generation.

(25) Christanis, K. Telma 1983, 13, 19-32.

(26) Melidonis, N. Telma 1981, 11, 41-63.

(27) Koukouzas, C.; Koukouzas, N. In European Coal Geology; Whateley, M. K. G., Spears, D. A., Eds.; Geological Society: London, 1995; Vol. 82, pp 126-145. 
Table 1. Analyzed Peat Samples

\begin{tabular}{|c|c|c|c|c|c|c|}
\hline & \multicolumn{6}{|c|}{ sample no. } \\
\hline & \multicolumn{2}{|c|}{ core Ph1 } & \multicolumn{2}{|c|}{ core Ph2 } & \multicolumn{2}{|c|}{ core Ph3 } \\
\hline & no. 1 & no. 2 & no. 3 & no. 4 & no. 5 & no. 6 \\
\hline sampling depth (cm) & $210-230$ & $560-580$ & $300-320$ & $650-670$ & $210-230$ & $640-660$ \\
\hline ash (wt \%, dry basis) & 21.9 & 32.0 & 36.3 & 37.9 & 40.7 & 36.8 \\
\hline
\end{tabular}

\section{Material and Methods}

Six peat samples (each $20 \mathrm{~cm}$ thick) were selected from three cores (Ph1-3; see Figure 1) obtained using a hand-driven Edel man auger. Since the stratigraphic evolution of the upper part of the Philippi peatland is well documented through radiocarbon dating, ${ }^{25}$ the sampling was as follows: in every core, the upper sample (nos. 1, 3, and 5) represents the Holocene peat and the deeper one (nos. 2, 4, and 6) represents the U pper Weichselian, especially the Pleniglacial peat (Figure 1 and Table 1 ).

The peat samples were air-dried, crushed to pass through the $1 \mathrm{~mm}$ sieve, homogenized, and divided into two bulk subsamples. The first sub-sample was treated with $\mathrm{H}_{2} \mathrm{O}_{2}$ (10wt $\% / v$ ) in order to remove the organic matter. The residues (wet ashes) were dried in an oven at $105{ }^{\circ} \mathrm{C}$ to constant weight; then they were analyzed using X-ray diffractometer and semiquantitatively evaluated. The second group of subsamples was combusted in a muffle furnace at $550^{\circ} \mathrm{C}$ for $4 \mathrm{~h}$, and the ash contents were determined. The combustion residues (peat ash samples) were analyzed for 43 trace elements using inductively coupled plasma-mass spectrometry (ICP-MS). A split of $0.1 \mathrm{~g}$ of peat ash was digested in $\mathrm{HNO}_{3}: \mathrm{HClO}_{4}: \mathrm{HF}(2.5$ : 2.5:5, v/v), doubly evaporated to incipient dryness with addition of $\mathrm{HNO}_{3}$ and finally made up to $100 \mathrm{~mL}$ in $1 \% \mathrm{HNO}_{3}$. The concentrations of $\mathrm{Ag}, \mathrm{As}, \mathrm{Ba}, \mathrm{Be}, \mathrm{Bi}, \mathrm{Cd}, \mathrm{Ce}, \mathrm{Co}, \mathrm{Cr}, \mathrm{Cs}, \mathrm{Cu}$, Dy, Er, Eu, Ga, Gd, Ge, Hf, Ho, La, Li, Mo, Nb, Nd, Ni, Pb, $\mathrm{Pr}, \mathrm{Rb}, \mathrm{Sb}, \mathrm{Sc}, \mathrm{Sm}, \mathrm{Sn}, \mathrm{Sr}, \mathrm{Ta}, \mathrm{Tb}, \mathrm{Th}, \mathrm{U}, \mathrm{V}, \mathrm{W}, \mathrm{Y}, \mathrm{Yb}, \mathrm{Zn}$, and $\mathrm{Zr}$ were determined in the final $1 \% \mathrm{HNO}_{3}$ solution.

\section{Results}

4.1. Mineralogical Determinations on Peat Wet Ash. The ash yields of the peat samples range between 21.9 and 40.7 wt \% (dry basis), which indicate inorganic input during peat accumulation (Table 1).

The mineralogical determinations on the wet ashes revealed that gypsum, calcite, quartz, clay minerals, and feldspars are the major mineral phases in the peat (Table 2). Feldspars are mostly represented by al bite, and in minor proportion by microcline, whereas clay minerals are mixed clay layers consisting mainly of illite. These minerals correspond to primary phases.

Table 2. Mineralogical Composition of Philippi Peat Wet Ashesa

\begin{tabular}{|c|c|c|c|c|c|c|}
\hline \multirow[b]{3}{*}{ mineral } & \multicolumn{6}{|c|}{ sample } \\
\hline & \multicolumn{2}{|c|}{ core Ph1 } & \multicolumn{2}{|c|}{ core Ph2 } & \multicolumn{2}{|c|}{ core Ph3 } \\
\hline & no. 1 & no. 2 & no. 3 & no. 4 & no. 5 & no. 6 \\
\hline quartz & $\mathrm{m}$ & $M$ & $\mathrm{~m}$ & $M$ & M & M \\
\hline illite & $\mathrm{m}$ & M & $\mathrm{m}$ & M & M & M \\
\hline feldspars & $\operatorname{tr}$ & $\operatorname{tr}$ & $\operatorname{tr}$ & $\operatorname{tr}$ & $\operatorname{tr}$ & $\operatorname{tr}$ \\
\hline $\begin{array}{l}\text { calcite } \\
\text { lime }\end{array}$ & M & $\begin{array}{l}\mathrm{m} \\
\mathrm{tr}\end{array}$ & M & $\mathrm{m}$ & M & M \\
\hline gypsum & $\mathrm{m}$ & $M$ & $\operatorname{tr}$ & $M$ & & \\
\hline anhydrite & $\operatorname{tr}$ & $\operatorname{tr}$ & & & & \\
\hline hematite & & & $\operatorname{tr}$ & $\operatorname{tr}$ & & \\
\hline $\begin{array}{l}\text { goethite } \\
\text { weddellite }\end{array}$ & $M$ & & $\mathrm{~m}$ & $\mathrm{~m}$ & $\operatorname{tr}$ & $\begin{array}{l}\operatorname{tr} \\
\operatorname{tr}\end{array}$ \\
\hline
\end{tabular}

a $M$, major; $m$, minor; tr, traces.
Hematite, goethite, anhydrite, lime, and weddellite occur subordinately and probably represent minerals that do not correspond to primary phases. Ward ${ }^{28}$ stated that treatment of the peat samples with $\mathrm{H}_{2} \mathrm{O}_{2}$ results in the breakdown of certain minerals and the formation of new phases. Weddel lite, a cal cium oxal ate, is usually the result of reactions between humic acids released from the organic matter and $\mathrm{Ca}$ ions released from either organic or inorganic compounds. ${ }^{28}$ Lime and anhydrite seem to form due to breakdown of calcite and the dehydration of gypsum, respectively. ${ }^{28,29}$ However, it seems that gypsum remains in the wet ashes due to incompl ete attack by $\mathrm{H}_{2} \mathrm{O}_{2}$. $\mathrm{H}$ ematite and goethite are probably products of pyrite oxidation, al though primary occurrence of very small quantities cannot be excluded.

Gypsum is present mainly in samples of core Ph1 (nos. 1 and 2) and in the Upper Weichselian sample of core Ph2 (no. 4). Quartz and clay minerals are major phases in the Upper Weichselian samples of Phl and Ph2 cores (nos. 2 and 4) and in both Holocene and U pper Weichselian samples of Ph3 core (nos. 5 and 6). In contrast, calcite is a major phase in the Holocene samples of cores Ph1 and Ph2 (nos. 1 and 3) and in both samples of Ph3 (nos. 5 and 6). These results suggest lateral and vertical variations of the peat-forming conditions in the Philippi peatland; that is, the mineral distribution within the peatland is strongly related to the original sedimentation processes.

4.2. Trace Elements Contents in Peat Ash. Although the concentrations of many elements have a wide range among the samples, in general, the most abundant trace elements are Ba (194-375 mg/kg), As $(88-420 \mathrm{mg} / \mathrm{kg}), \mathrm{Sr}(85-245 \mathrm{mg} / \mathrm{kg}), \mathrm{Zn}(79-188 \mathrm{mg} /$ $\mathrm{kg}), \mathrm{V}(27-176 \mathrm{mg} / \mathrm{kg}), \mathrm{Cr}(27-222 \mathrm{mg} / \mathrm{kg}), \mathrm{Rb}(34-$ $154 \mathrm{mg} / \mathrm{kg}), \mathrm{U}(11-208 \mathrm{mg} / \mathrm{kg})$, Mo (8-291 mg/kg), and $\mathrm{Pb}$ (19-150 mg/kg; see Table 3). The elements Ce, Co, $\mathrm{Cs}, \mathrm{Cu}, \mathrm{Ga}, \mathrm{La}, \mathrm{Li}, \mathrm{Nb}, \mathrm{Nd}, \mathrm{Ni}, \mathrm{Sb}, \mathrm{Sc}, \mathrm{Th}, \mathrm{W}, \mathrm{Y}$, and $\mathrm{Zr}$ show values between 10 and $100 \mathrm{mg} / \mathrm{kg}$, while the concentrations of $\mathrm{Ag}, \mathrm{Be}, \mathrm{Bi}, \mathrm{Cd}, \mathrm{Dy}, \mathrm{Er}, \mathrm{Eu}, \mathrm{Gd}, \mathrm{Ge}$, $\mathrm{Hf}, \mathrm{Ho}, \mathrm{Pr}, \mathrm{Sm}, \mathrm{Sn}, \mathrm{Ta}, \mathrm{Tb}$, and $\mathrm{Yb}$ do not exceed 10 $\mathrm{mg} / \mathrm{kg}$.

To understand the interrelations of the trace elements, the Pearson correlation coefficients were cal culated. Most of the el ements show positive correlation to each other. Only $\mathrm{Sr}$ correlates negatively with the majority of the elements, and particularly with As, $Y$, $\mathrm{Cr}, \mathrm{Er}, \mathrm{Ga}, \mathrm{Eu}, \mathrm{Li}$, and $\mathrm{Sb}\left(\mathrm{R}_{\mathrm{p}}<-0.8\right)$, indicating a different mode of occurrence for $\mathrm{Sr}$ within peat. The following elements show strong positive correlation $(>0.9)$ to each other: $\mathrm{As}-\mathrm{Sb}, \mathrm{Ba}-\mathrm{Zn}, \mathrm{Bi}-\mathrm{Pb}, \mathrm{Cd}-\mathrm{Cr}-$ $\mathrm{Y}, \mathrm{Ge}-\mathrm{Pb}, \mathrm{Nb}-\mathrm{W}$, and $\mathrm{Mo}-\mathrm{U}-\mathrm{W}$. A comparison with the correlation matrix of the bulk peat data already published ${ }^{22}$ shows that $\mathrm{Sr}$ correlates negatively with the

(28) Ward, C. R. Aust. Coal Geol. 1986, 6, 87-110.

(29) Querol, X.; Fernández-Turiel, J . L.; López-Soler, A. Mineral. Mag. 1994, 58, 119-133. 
Table 3. Trace Elements Concentrations (in $\mathrm{mg} / \mathrm{kg}$ ) in the Philippi Peat Ashes

\begin{tabular}{ccccccc}
\hline & \multicolumn{7}{c}{ sample } \\
element & no. 1 & no. 2 & no. 3 & no. 4 & no. 5 & no. 6 \\
\hline $\mathrm{Ag}$ & 1.0 & 0.4 & 0.2 & 0.3 & 0.5 & 1.0 \\
$\mathrm{As}$ & 153 & 188 & 88 & 92 & 455 & 420 \\
$\mathrm{Ba}$ & 375 & 268 & 194 & 320 & 273 & 241 \\
$\mathrm{Be}$ & 2.6 & 4.5 & 0.7 & 2.6 & 3.5 & 3.7 \\
$\mathrm{Bi}$ & 1.5 & 0.6 & 0.7 & 0.7 & 0.9 & 0.8 \\
$\mathrm{Cd}$ & 1.2 & 1.0 & 0.2 & 0.3 & 2.4 & 1.2 \\
$\mathrm{Ce}$ & 55 & 81 & 21 & 62 & 65 & 60 \\
$\mathrm{Co}$ & 11.1 & 13.0 & 4.6 & 13.3 & 12.7 & 15.8 \\
$\mathrm{Cr}$ & 90 & 118 & 27 & 94 & 222 & 136 \\
$\mathrm{Cs}$ & 18.7 & 23.9 & 1.8 & 6.9 & 13.9 & 15.1 \\
$\mathrm{Cu}$ & 43 & 40 & 17 & 35 & 38 & 33 \\
$\mathrm{Dy}$ & 4.3 & 5.3 & 1.1 & 4.2 & 5.8 & 5.1 \\
$\mathrm{Er}$ & 2.1 & 2.8 & 0.5 & 2.2 & 3.2 & 3.0 \\
$\mathrm{Eu}$ & 0.9 & 1.4 & 0.4 & 1.2 & 1.4 & 1.3 \\
$\mathrm{Ga}$ & 16.4 & 20.7 & 5.5 & 16.1 & 23.5 & 22.1 \\
$\mathrm{Gd}$ & 5.2 & 6.7 & 1.4 & 4.9 & 6.8 & 6.0 \\
$\mathrm{Ge}$ & 7.2 & 4.0 & 0.2 & 1.1 & 2.1 & 3.1 \\
$\mathrm{Hf}$ & 2.2 & 2.4 & 0.2 & 1.4 & 2.2 & 1.8 \\
$\mathrm{Ho}$ & 0.8 & 1.0 & 0.2 & 0.8 & 1.2 & 1.0 \\
$\mathrm{La}$ & 24 & 35 & 8 & 24 & 27 & 25 \\
$\mathrm{Li}$ & 34 & 55 & 10 & 33 & 60 & 43 \\
$\mathrm{Mo}$ & 147 & 291 & 8 & 9 & 35 & 39 \\
$\mathrm{Nb}$ & 9.7 & 19.8 & 3.9 & 6.1 & 11.3 & 12.4 \\
$\mathrm{Nd}$ & 27 & 36 & 9 & 29 & 33 & 31 \\
$\mathrm{Ni}$ & 16 & 17 & 8 & 17 & 17 & 17 \\
$\mathrm{~Pb}$ & 150 & 45 & 19 & 25 & 32 & 26 \\
$\mathrm{Pr}$ & 6.9 & 10.1 & 2.5 & 7.5 & 8.5 & 8.1 \\
$\mathrm{Rb}$ & 98 & 154 & 34 & 133 & 118 & 117 \\
$\mathrm{Sb}$ & 13.2 & 15.8 & 3.4 & 1.8 & 23.8 & 24.1 \\
$\mathrm{Sc}$ & 10.8 & 11.8 & 2.9 & 10.1 & 10.9 & 10.5 \\
$\mathrm{Sm}$ & 5.0 & 6.4 & 1.5 & 5.2 & 5.9 & 5.4 \\
$\mathrm{Sn}$ & 3.2 & 3.7 & 1.6 & 1.5 & 2.5 & 3.0 \\
$\mathrm{Sr}$ & 243 & 164 & 245 & 190 & 85 & 110 \\
$\mathrm{Ta}$ & 0.8 & 0.9 & 0.1 & 0.4 & 0.5 & 0.6 \\
$\mathrm{~Tb}$ & 0.9 & 0.9 & 0.3 & 0.8 & 1.0 & 0.9 \\
$\mathrm{Th}$ & 13.9 & 13.8 & 4.6 & 12.1 & 14.8 & 13.3 \\
$\mathrm{U}$ & 179 & 208 & 25 & 11 & 98 & 53 \\
$\mathrm{~V}$ & 160 & 176 & 27 & 95 & 152 & 143 \\
$\mathrm{~W}$ & 24.6 & 36.4 & 2.6 & 3.9 & 12.0 & 16.3 \\
$\mathrm{Y}$ & 17.3 & 28.9 & 4.5 & 20.0 & 36.0 & 29.5 \\
$\mathrm{Yb}$ & 2.1 & 2.5 & 0.5 & 2.2 & 2.9 & 2.7 \\
$\mathrm{Zn}$ & 188 & 154 & 79 & 168 & 152 & 131 \\
$\mathrm{Zr}$ & 60 & 86 & 8 & 47 & 78 & 58 \\
$\mathrm{Hr}$ & & & & & &
\end{tabular}

Table 4. Results of Pearson Correlation Coefficients Analyses on the Trace Element Contents in the Ash Samples Presented in this Study and that of Bulk Peat Samples from Christanis et al. ${ }^{22}$

\begin{tabular}{ll}
\multicolumn{1}{c}{$\begin{array}{c}\text { correlation in } \\
\text { bulk peat samples }\end{array}$} & \multicolumn{1}{c}{$\begin{array}{c}\text { correlation in } \\
\text { ash samples }\end{array}$} \\
\hline $\mathrm{Ag}-\mathrm{Cs}-\mathrm{Ga}-\mathrm{Ge}-\mathrm{Sb}-\mathrm{V}-\mathrm{W}-\mathrm{Y}-\mathrm{Yb}$ & $\mathrm{Ag}-\mathrm{Ge}$ \\
$\mathrm{As}-\mathrm{Ba}-\mathrm{Bi}-\mathrm{Cu}-\mathrm{Er}-\mathrm{Ga}-\mathrm{Gd}-\mathrm{Ho}-\mathrm{Li}-$ & $\mathrm{As}-\mathrm{Cd}-\mathrm{Cr}-\mathrm{Er}-$ \\
$\mathrm{Nd}-\mathrm{Sn}-\mathrm{Y}$ & $\mathrm{Ga}-\mathrm{Y}-\mathrm{Yb}$ \\
$\mathrm{Cd}-\mathrm{Zn}$ & $\mathrm{Cd}-\mathrm{Cr}$ \\
$\mathrm{Ge}-\mathrm{W}$ & $\mathrm{Ge}-\mathrm{Pb}$ \\
$\mathrm{Nb}-\mathrm{Nd}-\mathrm{Pr}-\mathrm{Rb}-\mathrm{Sc}-\mathrm{Sm}-\mathrm{Sn}-\mathrm{Tb}-\mathrm{Th}-$ & \\
$\mathrm{V}-\mathrm{Y}-\mathrm{Yb}-\mathrm{Zr}$ & $\mathrm{Cu}-\mathrm{Ni}$ and $\mathrm{Cu}-\mathrm{Ba}$ \\
$\mathrm{Ni}-\mathrm{Ba}-\mathrm{Cu}$ & $\mathrm{Bi}-\mathrm{Pb}$
\end{tabular}

majority of the trace elements suggesting a different mode of occurrence in both bulk peat and peat ash. However, it is interesting to compare possible differences between both correlation matrixes, since changes in the affinity of the trace elements during combustion can be evident. The most characteristic changes are summarized in Table 4. The alterations in the grouping of the trace elements $\mathrm{Ag}, \mathrm{As}, \mathrm{Ba}, \mathrm{Bi}, \mathrm{Cd}, \mathrm{Cr}, \mathrm{Ge}, \mathrm{Nb}$, $\mathrm{Ni}, \mathrm{Pb}$, and $\mathrm{W}$ can be regarded as a result of chemical reactions that occurred during combustion and significantly affect the behavior of these el ements.
The data set of the trace elements in the peat ashes was further evaluated using factor analysis. Comparing the results to those of the bulk peat data set (Table 5), it is revealed that $\mathrm{Ag}, \mathrm{Ba}, \mathrm{Nb}, \mathrm{Pb}, \mathrm{Sn}$ and $\mathrm{Zn}$ are associated within different groups in the ash than in the bulk samples. This probably indicates a change in the mode of occurrence of these elements due to combustion. Moreover, $Y$ and $\mathrm{Ga}$ are clustered within both GI and GIII groups (Table 5), indicating possibly a minor change in the mode of occurrence. According to the factor scores, grouping of trace elements in $\mathrm{Gl}$ and GI groups is intensely observed in nos. 2, 4, 5 and 6, while groups G2 and GII significantly occur in nos. 1 and 3 (Table 5).

4.3. Trace Element Enrichment in the Ash. To approach the mobility of each trace element, the relative enrichment factor (RE) introduced by Meij ${ }^{12}$ was calculated. RE is defined by the formula:

$$
R E=\frac{T E_{\text {ash }} A}{T_{\text {bulk }} 100}
$$

where $T E_{\text {ash: }}$ trace element concentration in peat ash, $\mathrm{TE}_{\text {bulk: }}$ :trace element concentration in bulk peat, $\mathrm{A}$ :ash yield at $550{ }^{\circ} \mathrm{C}$ in weight percentage.

Meij ${ }^{12}$ applied RE calculations in both bottom and fly ashes from Dutch coal-fired power plants, and grouped the trace elements according to both bottom and fly ash $R E$ values. We calculated the RE in the peat ashes produced in the laboratory and we assume that trace elements that display RE values between 0.7 and 0.5 are moderately and $<0.5$ are intensely depleted, respectively, from the ash and can be regarded as potentially volatile elements. The most depleted trace elements according to $\mathrm{RE}_{\text {mean }}$ are (in order of decreasing volatility potential): $\mathrm{Ag}>\mathrm{Cd} \sim \mathrm{Sc}>\mathrm{As}>\mathrm{Tb}>\mathrm{Sn}>\mathrm{Ta}>\mathrm{Sr}>$ $\mathrm{Zn}>\mathrm{Ho}>\mathrm{Ge}>\mathrm{Hf}>\mathrm{Ba}>\mathrm{Mo}>\mathrm{Be}$ (Table 6). On the other hand, the most stable elements $\left(\mathrm{RE}_{\text {mean }}>0.9\right)$ are $\mathrm{Cr}, \mathrm{La}, \mathrm{Li}, \mathrm{Rb}$, and $\mathrm{V}$. The remaining elements reveal an intermediate behavior $\left(0.8<\mathrm{RE}_{\text {mean }}<0.9\right)$. However, the RE values of most trace elements are highly variable among the samples (Table 6). This could be evidence of the influence of the primary nature of the peat samples, which additionally depends on the depositional conditions. To understand the nature of this discrimination, as well as to assess possible interrelationships of the trace elements mobility, we applied factor analysis on the RE data. R-mode factor analyses revealed a 3-factor model, which accounts for $78 \%$ of the total variation. All factors display bipolar mode and the grouping of the trace elements, as well as the ranges of factor loading are presented in Table 7. The subdivision according to the factors is inferred to the common relevant enrichment or depletion of the trace elements in the ash. The bipolar mode of the factors suggests that there are significant combustion behavior differences among the elements, which are related to the nature of the samples. Combining the factor loading data (Table 7) with the factor scores of each sample (Figure 2), it is revealed that the elements $\mathrm{W}, \mathrm{As}, \mathrm{Mo}, \mathrm{Cd}, \mathrm{Sb}$, and to a lesser extent $\mathrm{Eu}, \mathrm{Tb}$ and $\mathrm{Ho}$ are more depleted in ash from nos. 1, 4, and 3. The elements $\mathrm{Gd}, \mathrm{Nb}$ and $\mathrm{Sn}$ are mainly depleted in ash from nos. 4, 5, and 6, and the 
Table 5. Results of R-Mode Factor Analyses on the Trace Elements Data Set of the Bulk Peat Samples after Christanis et al.,22 as well as of the Peat Ashes (Elements in Bold Have Changed Affinity)

\begin{tabular}{llll}
\hline \multicolumn{2}{c}{ groups of R-mode factor analyses on bulk peat data set } & & groups of R-mode factor analyses on peat ash data set \\
\hline G1 & $\mathrm{REE}-\mathrm{Be}-\mathrm{Co}-\mathrm{Ga}-\mathrm{Hf}-\mathbf{N b}-\mathrm{Li}-\mathrm{Rb}-\mathrm{Sc}-\mathrm{Sn}-\mathrm{Th}-\mathrm{V}-\mathrm{Y}-\mathrm{Zr}$ & $\mathrm{Gl}$ & $\mathrm{REE}-\mathrm{Be}-\mathrm{Co}-\mathrm{Ga}-\mathrm{Hf}-\mathrm{Li}-\mathrm{Rb}-\mathrm{Sc}-\mathrm{Th}-\mathrm{V}-\mathrm{Y}-\mathrm{Zn}-\mathrm{Zr}$ \\
$\mathrm{G} 2$ & $\mathrm{Sr}-\mathbf{P b}$ & $\mathrm{GII}$ & $\mathrm{Sr}$ \\
$\mathrm{G} 3$ & $\mathrm{As}-\mathrm{Bi}-\mathrm{Cd}-\mathrm{Cr}-\mathrm{Cu}-\mathrm{Ni}-\mathrm{Sb}-\mathbf{Z n}$ & $\mathrm{GlIl}$ & $\mathrm{As}-\mathrm{Cd}-\mathrm{Sb}-\mathrm{Cr}-\mathbf{Y}-\mathbf{G a}$ \\
$\mathrm{G} 4$ & $\mathbf{A g}-\mathrm{Cs}-\mathrm{Ge}-\mathrm{Mo}-\mathrm{Pb}-\mathrm{Ta}-\mathrm{U}-\mathrm{W}$ & $\mathrm{GIV}$ & $\mathrm{Mo}-\mathrm{W}-\mathbf{N b}-\mathrm{Sn}-\mathrm{U}-\mathrm{Cs}-\mathrm{Ta}-\mathrm{Ge}-\mathrm{V}$
\end{tabular}

Table 6. Trace Element Concentrations in the Bulk Peat Samplesa and Relative Enrichment Factors of the Trace Elements in the Ash Samples Using the Formula of Meij ${ }^{b}$

\begin{tabular}{|c|c|c|c|c|c|c|c|c|c|c|c|c|c|}
\hline \multirow[b]{2}{*}{ element } & \multicolumn{6}{|c|}{ concentrations on bulk peat samples (mg/kg) } & \multicolumn{7}{|c|}{ relative enrichment factor in the ash samples } \\
\hline & 1 & 2 & 3 & 4 & 5 & 6 & 1 & 2 & 3 & 4 & 5 & 6 & mean \\
\hline $\mathrm{Ag}$ & 0.5 & 0.5 & 0.2 & 0.3 & 0.5 & 0.7 & 0.44 & 0.26 & 0.35 & 0.36 & 0.37 & 0.56 & 0.39 \\
\hline As & 87.1 & 113.9 & 82.3 & 104.1 & 296.1 & 259.8 & 0.38 & 0.53 & 0.39 & 0.34 & 0.63 & 0.59 & 0.48 \\
\hline $\mathrm{Ba}$ & 104.1 & 149.6 & 99.9 & 155.4 & 224.3 & 134.0 & 0.79 & 0.57 & 0.71 & 0.78 & 0.49 & 0.66 & 0.67 \\
\hline $\mathrm{Be}$ & 0.9 & 2.1 & 0.5 & 1.3 & 2.1 & 1.6 & 0.61 & 0.70 & 0.48 & 0.74 & 0.69 & 0.87 & 0.68 \\
\hline $\mathrm{Bi}$ & 0.3 & 0.4 & 0.5 & 0.3 & 0.6 & 0.5 & 1.01 & 0.46 & 0.56 & 0.93 & 0.61 & 0.63 & 0.70 \\
\hline $\mathrm{Cd}$ & 0.8 & 0.7 & 0.4 & 0.4 & 1.4 & 0.6 & 0.33 & 0.43 & 0.18 & 0.31 & 0.70 & 0.70 & 0.44 \\
\hline $\mathrm{Ce}$ & 13.4 & 35.1 & 7.4 & 24.1 & 35.5 & 27.8 & 0.90 & 0.74 & 1.01 & 0.97 & 0.74 & 0.80 & 0.86 \\
\hline Co & 2.9 & 4.9 & 2.3 & 5.5 & 5.5 & 5.9 & 0.84 & 0.86 & 0.72 & 0.92 & 0.94 & 1.00 & 0.88 \\
\hline $\mathrm{Cr}$ & 20.3 & 40.9 & 12.6 & 35.2 & 91.3 & 53.1 & 0.97 & 0.92 & 0.79 & 1.01 & 0.99 & 0.95 & 0.94 \\
\hline Cs & 4.1 & 8.9 & 0.9 & 3.0 & 6.5 & 6.2 & 1.00 & 0.86 & 0.73 & 0.88 & 0.87 & 0.90 & 0.87 \\
\hline $\mathrm{Cu}$ & 14.1 & 17.8 & 10.1 & 18.1 & 35.3 & 16.2 & 0.67 & 0.72 & 0.60 & 0.74 & 0.44 & 0.75 & 0.65 \\
\hline Dy & 1.0 & 2.4 & 0.5 & 2.0 & 2.6 & 2.2 & 0.92 & 0.72 & 0.86 & 0.80 & 0.91 & 0.86 & 0.85 \\
\hline $\mathrm{Er}$ & 0.6 & 1.3 & 0.4 & 0.9 & 1.7 & 1.2 & 0.78 & 0.67 & 0.48 & 0.91 & 0.78 & 0.92 & 0.76 \\
\hline $\mathrm{Eu}$ & 0.4 & 0.7 & 0.2 & 0.6 & 0.7 & 0.6 & 0.56 & 0.66 & 0.72 & 0.69 & 0.77 & 0.76 & 0.69 \\
\hline $\mathrm{Ga}$ & 4.1 & 9.0 & 2.5 & 7.3 & 12.0 & 10.0 & 0.89 & 0.74 & 0.78 & 0.84 & 0.80 & 0.81 & 0.81 \\
\hline $\mathrm{Gd}$ & 1.1 & 2.8 & 0.5 & 2.5 & 3.3 & 2.8 & 1.01 & 0.75 & 1.00 & 0.74 & 0.83 & 0.79 & 0.85 \\
\hline $\mathrm{Ge}$ & 1.6 & 1.7 & 0.2 & 0.8 & 1.4 & 1.4 & 1.00 & 0.75 & 0.28 & 0.51 & 0.61 & 0.79 & 0.66 \\
\hline $\mathrm{Hf}$ & 0.5 & 1.2 & 0.3 & 0.9 & 1.2 & 0.9 & 0.98 & 0.62 & 0.29 & 0.61 & 0.75 & 0.72 & 0.66 \\
\hline $\mathrm{Ho}$ & 0.3 & 0.5 & 0.2 & 0.5 & 0.7 & 0.5 & 0.56 & 0.59 & 0.38 & 0.62 & 0.73 & 0.73 & 0.60 \\
\hline La & 5.3 & 14.4 & 3.0 & 10.0 & 13.1 & 10.5 & 0.99 & 0.77 & 0.98 & 0.92 & 0.83 & 0.89 & 0.90 \\
\hline $\mathrm{Li}$ & 9.2 & 20.1 & 3.7 & 13.3 & 25.6 & 17.3 & 0.80 & 0.88 & 1.02 & 0.94 & 0.95 & 0.92 & 0.92 \\
\hline Mo & 49.3 & 124.9 & 4.9 & 5.4 & 17.9 & 22.1 & 0.65 & 0.74 & 0.56 & 0.62 & 0.79 & 0.66 & 0.67 \\
\hline $\mathrm{Nb}$ & 2.7 & 6.4 & 1.5 & 5.3 & 7.4 & 4.9 & 0.79 & 0.99 & 0.96 & 0.44 & 0.62 & 0.94 & 0.79 \\
\hline $\mathrm{Nd}$ & 6.4 & 14.8 & 3.7 & 11.9 & 16.7 & 13.3 & 0.94 & 0.79 & 0.90 & 0.93 & 0.79 & 0.85 & 0.87 \\
\hline $\mathrm{Ni}$ & 4.4 & 7.3 & 6.2 & 6.9 & 11.0 & 6.2 & 0.78 & 0.76 & 0.45 & 0.95 & 0.64 & 1.00 & 0.76 \\
\hline $\mathrm{Pb}$ & 37.8 & 23.2 & 9.3 & 12.4 & 17.9 & 12.3 & 0.87 & 0.62 & 0.76 & 0.77 & 0.73 & 0.79 & 0.76 \\
\hline $\mathrm{Pr}$ & 2.0 & 4.6 & 1.1 & 3.1 & 4.3 & 3.6 & 0.76 & 0.71 & 0.85 & 0.92 & 0.80 & 0.83 & 0.81 \\
\hline $\mathrm{Rb}$ & 22.9 & 59.6 & 13.2 & 53.7 & 56.0 & 44.9 & 0.94 & 0.82 & 0.94 & 0.94 & 0.86 & 0.96 & 0.91 \\
\hline $\mathrm{Sb}$ & 3.3 & 5.1 & 2.4 & 1.4 & 12.0 & 9.5 & 0.89 & 0.99 & 0.53 & 0.50 & 0.81 & 0.94 & 0.78 \\
\hline Sc & 4.7 & 8.8 & 5.1 & 7.3 & 8.5 & 7.3 & 0.51 & 0.43 & 0.21 & 0.52 & 0.52 & 0.53 & 0.45 \\
\hline Sm & 1.1 & 3.0 & 0.7 & 2.1 & 3.0 & 2.6 & 0.97 & 0.67 & 0.84 & 0.94 & 0.80 & 0.76 & 0.83 \\
\hline $\mathrm{Sn}$ & 1.1 & 1.8 & 1.0 & 1.9 & 2.4 & 1.6 & 0.61 & 0.67 & 0.57 & 0.31 & 0.42 & 0.67 & 0.54 \\
\hline $\mathrm{Sr}$ & 80.9 & 101.0 & 134.5 & 110.1 & 78.1 & 77.9 & 0.66 & 0.52 & 0.66 & 0.65 & 0.44 & 0.52 & 0.58 \\
\hline $\mathrm{Ta}$ & 0.2 & 1.6 & 0.2 & 0.2 & 0.3 & 0.6 & 0.86 & 0.17 & 0.16 & 1.01 & 0.74 & 0.36 & 0.55 \\
\hline $\mathrm{Tb}$ & 0.4 & 0.6 & 0.3 & 0.6 & 0.6 & 0.6 & 0.50 & 0.52 & 0.36 & 0.53 & 0.67 & 0.57 & 0.52 \\
\hline $\mathrm{Th}$ & 3.6 & 7.2 & 1.8 & 6.2 & 7.7 & 5.7 & 0.84 & 0.61 & 0.91 & 0.74 & 0.78 & 0.86 & 0.79 \\
\hline$U$ & 56.5 & 89.0 & 11.2 & 5.4 & 52.7 & 26.1 & 0.69 & 0.75 & 0.80 & 0.80 & 0.76 & 0.75 & 0.76 \\
\hline V & 38.2 & 60.5 & 10.3 & 39.7 & 68.2 & 52.8 & 0.91 & 0.93 & 0.95 & 0.91 & 0.91 & 1.00 & 0.93 \\
\hline W & 7.8 & 11.8 & 1.2 & 1.7 & 5.5 & 7.0 & 0.69 & 0.99 & 0.79 & 0.84 & 0.88 & 0.86 & 0.84 \\
\hline$Y$ & 4.6 & 12.2 & 2.0 & 8.3 & 14.7 & 11.4 & 0.83 & 0.76 & 0.83 & 0.92 & 1.00 & 0.95 & 0.88 \\
\hline $\mathrm{Yb}$ & 0.5 & 1.1 & 0.2 & 0.9 & 1.2 & 1.1 & 1.00 & 0.73 & 0.83 & 0.86 & 0.97 & 0.87 & 0.88 \\
\hline $\mathrm{Zn}$ & 86.4 & 90.4 & 52.3 & 79.0 & 122.5 & 77.2 & 0.48 & 0.55 & 0.55 & 0.81 & 0.50 & 0.62 & 0.58 \\
\hline $\mathrm{Zr}$ & 13.3 & 40.1 & 5.9 & 31.0 & 36.4 & 28.3 & 0.99 & 0.69 & 0.50 & 0.58 & 0.87 & 0.75 & 0.73 \\
\hline
\end{tabular}

a Reference 22. ${ }^{\mathrm{b}}$ Reference 12.

Table 7. Results of R-Mode Factor Analyses on the RE Data

\begin{tabular}{cc}
\hline factor & factor loading and clustering in positiver \\
\hline $\mathrm{F} 1$ & $>0.9: \mathrm{La}, \mathrm{Nd}, \mathrm{Sm}$ \\
$\mathrm{F} 2$ & $>0.7: \mathrm{Ba}, \mathrm{Bi}, \mathrm{Ce}, \mathrm{Ga}, \mathrm{Pb}, \mathrm{Rb}, \mathrm{Sr}$ \\
& $>0.9: \mathrm{Co}, \mathrm{Cr}, \mathrm{Er}, \mathrm{Sc}$ \\
$\mathrm{F} 3$ & $>0.7: \mathrm{Ge}, \mathrm{Hf}, \mathrm{Zr}, \mathrm{Cs}, \mathrm{Sb}$
\end{tabular}

elements $\mathrm{Ge}, \mathrm{Hf}, \mathrm{Zr}, \mathrm{Cs}$, and $\mathrm{Sb}$ are depleted in ash from nos. 3 and 4 . These observations lead also to the conclusion that samples from the cores Ph1 and Ph2 have major differences concerning the trace element mobility during combustion of the younger Holocene samples (nos. 1 and 3) compared to the older Upper Weichselian samples (nos. 2 and 4), respectively. The younger (no. 5) and the older (no. 6) peat samples from factor loading and clustering in negative pole

$$
\begin{aligned}
& <-0.5: \text { W, As, Mo, Cd, Sb } \\
& >-0.5: \text { Eu, Tb, Ho } \\
& <-0.4: \text { Gd, Nb, Sn } \\
& <-0.7: \text { U, Li, Pr, Zn }
\end{aligned}
$$

core $\mathrm{Ph} 3$ display almost similar trace el ement behavior during combustion.

\section{Discussion}

5.1. Concepts of Trace Element Geochemical Features in the Philippi Peatland. Previous stud$i^{22,24,25}$ on bulk peat samples concluded that the peat 


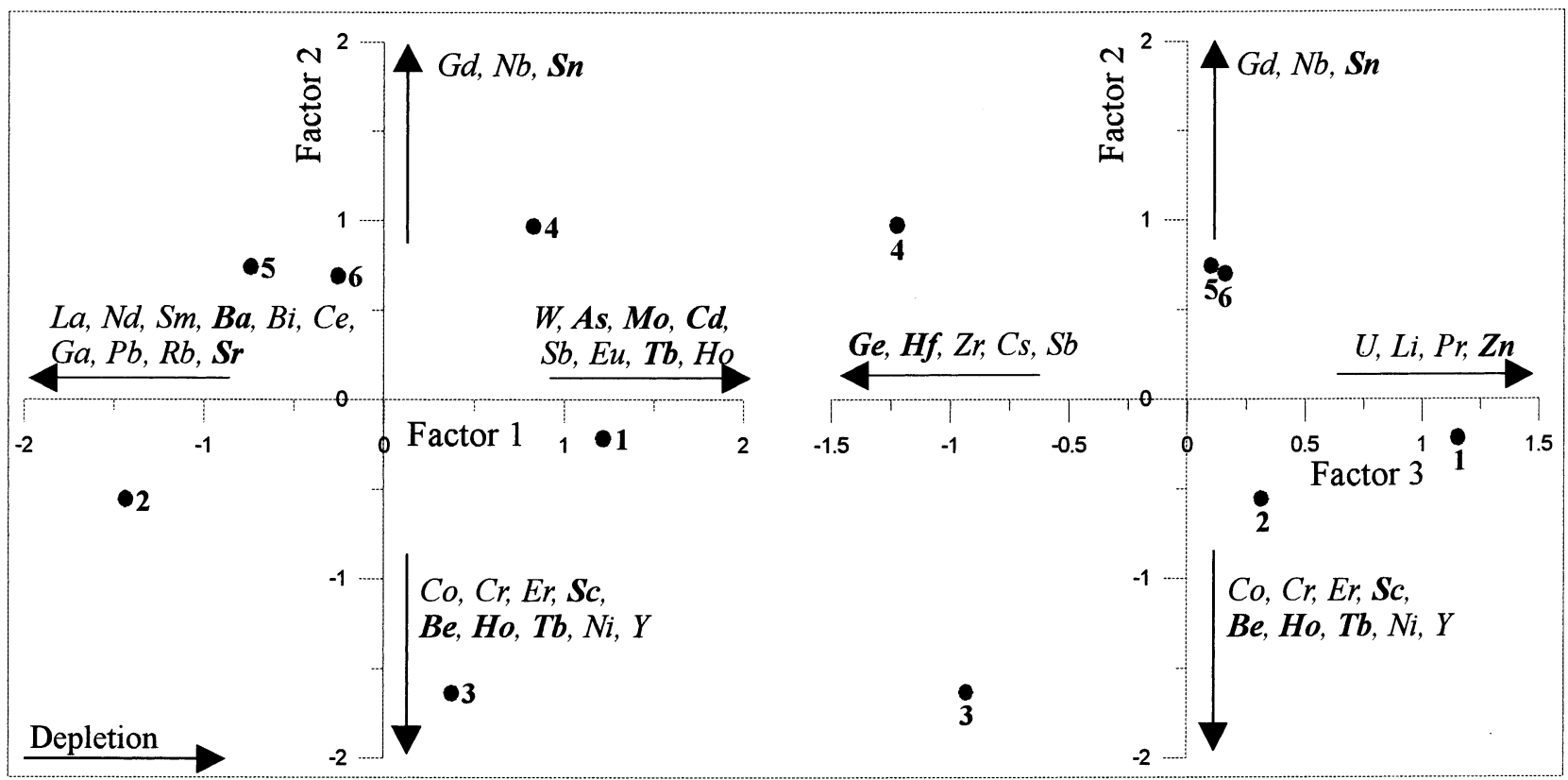

Figure 2. Scatter plot of factor scores and depletion tendency of each group of elements to the samples (1-6 ash samples; elements in bold show RE < 0.7).

accumulation conditions in the area of Philippi were drastically changed in the transition from Upper Weichselian to the Holocene due to the general amelioration of the climatic conditions. Particularly, the mineralogical and the geochemical features of the peat layers display significant differences between the two peat-forming facies. In general terms, peat accumulation during Holocene times was mainly affected by authigenic formation of carbonates with minor occurrence of gypsum and detrital minerals. In contrast, the Upper Weichselian peat was intensely affected by clastic sedimentation of aluminosilicates and authigenic formation of gypsum. The reason for this alteration may be that the amelioration of the climatic conditions toward a more humid climate was conducive to the enhanced activity of the karstic springs surrounding the peatland and consequently, to the increased $\mathrm{CaCO}_{3}$ supply to the fen. However, divergences from this trend were also observed, particularly at the marginal areas of the peatland.

In a previous paper, ${ }^{22}$ bulk peat samples from the Ph1, Ph2, and Ph3 cores (Figure 1) were analyzed for trace element contents. It was concluded that at the sites Ph1 and Ph2, peat accumulation followed the previous mentioned pattern, whereas core $\mathrm{Ph} 3$ showed the opposite trend. Moreover, in cores Ph1 and Ph2 the ash and the trace elements show lower values in the Holocene than in the U pper Weichselian peat (Table 6). Only $\mathrm{Cd}$ and $\mathrm{Pb}$ in the $\mathrm{Phl}$ core and $\mathrm{Bi}, \mathrm{Sb}, \mathrm{Sr}$, and $\mathrm{U}$ at site Ph2 show the opposite trend. In the Ph3 core, most of the trace elements are more enriched in the Holocene peat than in the Upper Weichselian peat, except for Ag, Co, Ge, Mo, Ta, and W. The statistical evaluation of bulk data reveals two sample groups (regarding the geochemical features): the first group consists of nos. 2, 4, 5 and 6, and the second group consists of nos. 1 and 3. The most likely mode of occurrence of the trace el ements at the studied sites can be summarized as follows:

- $\mathrm{Sr}, \mathrm{Pb}$, associated with carbonate minerals;
- REE, Be, Co, Ga, Hf, Li, Nb, Rb, Sc, Sn, Th, V, Y, and $\mathrm{Zr}$ with aluminosilicate minerals;

- As, Bi, Cd, Cr, Cu, Ni, Sb, and $\mathrm{Zn}$, heavy minerals associated with sulfides;

- Ag, Cs, Ge, Mo, Pb, Ta, U, and W, elements affiliated with the organic matter.

The modes of occurrences as described above are more or less in accordance with the results of similar studies on high rank coals.1,2

On the basis of the above-mentioned concept but also on the mineralogical data (Table 2), the studied samples are distinguished into three different sets: nos. 2 and 4 are richer in quartz, clay minerals, feldspars, and gypsum than nos. 1 and 3, which contain more carbonates, whereas nos. 5 and 6 are characterized by common major occurrence of aluminosilicates and carbonates.

5.2. Behavior of Trace Elements during Combustion. The comparative study of the trace element contents of bulk peat samples and their ashes, RE (Table 6), provides valuable information about the mobility of the trace elements during combustion. It is concluded that Ag, Cd, Sc, As, Tb, Sn, Ta, Sr, Zn, Ho, $\mathrm{Ge}, \mathrm{Hf}, \mathrm{Ba}, \mathrm{Mo}$, and Be show increased tendency to volatilize at $550^{\circ} \mathrm{C}$. This coincides in general terms with the results and interpretations of similar studies on coals from several basins. 10,12,21 However, divergences are observed for Sc, Sr, and $\mathrm{Hf}$, which reveal much more intense volatilization in the Philippi peat than in the coal samples studied by Meij. ${ }^{12}$ Additionally, the elements $\mathrm{Er}$ and $\mathrm{Ni}$ show intense depletion in nos. 3 and 4 , and moreover $\mathrm{Sb}$ and $\mathrm{Zr}$ are strongly depleted in nos. 3. All the other elements in the latter sample, i.e., Bi, $\mathrm{Ce}, \mathrm{Co}, \mathrm{Cr}, \mathrm{Cs}, \mathrm{Cu}, \mathrm{Dy}, \mathrm{Er}, \mathrm{Eu}, \mathrm{Ga}, \mathrm{Gd}, \mathrm{Ho}, \mathrm{La}, \mathrm{Li}, \mathrm{Nb}$, $\mathrm{Nd}, \mathrm{Pb}, \mathrm{Pr}, \mathrm{Rb}, \mathrm{Sm}, \mathrm{Th}, \mathrm{U}, \mathrm{V}, \mathrm{W}, \mathrm{Y}$, and $\mathrm{Yb}$ are more or less condensed in the ash.

Comparing the mode of occurrence as already described above and the volatilization tendencies of the studied trace elements (Table 7 ), it is revealed that of the organic affiliated el ements, Ag, Ta, Ge, and Mo are more depleted than $\mathrm{Cs}, \mathrm{Pb}, \mathrm{U}$, and $\mathrm{W}$. Moreover, the 
elements Sb, Tb, Sn, Ho, Hf, Be, Er, and Zr are affiliated with aluminosilicate minerals, $\mathrm{Sr}$ with carbonates, $\mathrm{Ba}$ probably with sulfates, and $\mathrm{Cd}, \mathrm{As}, \mathrm{Zn}, \mathrm{Ni}$, and $\mathrm{Sb}$ with sulfides (e.g., pyrite) are depleted in the ash. Hence, it can be assumed that in the Philippi peat the breakdown of pyrite, clay minerals, feldspars, carbonates, and sulfates affects significantly the mobility of the trace elements.

The statistical interpretations lead to the conclusion that the trace element partition varies among the samples suggesting variations in the chemical reactions, which take place during combustion. These variations are mainly related to the distribution of each mineral within peat, which depends on the geological conditions (kind and intensity of inorganic influx) prevailed during peat accumulation and humification.

Studies on New Zealand coals ${ }^{30}$ show that events taking place during the deposition stage, such as marine influence or deposition of volcanic ash, have a major influence on the partitioning behavior of the trace elements, particularly regarding the elements As, B, and $\mathrm{Se}$. The relationships between trace element partitioning and coal deposition conditions al so have been inferred in coal districts of Spain, China, and Turkey. ${ }^{31-33}$ In the case of the Philippi peat, it is inferred that the scattered mobility and partition of the trace elements across the samples are related to the initial depositional conditions that influenced the peat. One of the most

(30) Clemens, A. H.; Deely, J . M.; Gong, D.; Moore, T. A.; Shearer, J. C. Fuel 2000, 79, 1781-1784.

(31) Querol, X.; Cabrera, LI.; Pickel, W.; López-Soler, A.; Hagemann, H. W.; Fernández-Turiel, J. L. Int. J . Coal Geol. 1996, 29, 67-91.

(32) Querol, X.; Alastuey, A.; López-Soler, A.; Plana, F.; FernándezTuriel, J. L.; Zheng, R.; Xu, W.; Zhuang, X.; Spiro, B. Int. J . Coal Geol 1997, 31, 89-109.

(33) Querol, X.; Whateley, M. K. G.; Fernández-Turiel, J . L.; Tuncali, E. Int. J. Coal Geol. 1997, 33, 255-271. important factors that controlled peat mineralogical and geochemical features was the climate. In this sense, the different partitioning behavior of trace elements in sample couples nos. 1 and 3 (Holocene) and nos. 2 and 4 (Upper Weichselian) can be explained. Moreover, the different mobility tendency of the trace elements in nos. 5 and 6 is explained due to the fact that core Ph3 is located at the southern margins of the peatland. There, inorganic input was more intense and almost similar for Weichselian and Holocene times, due to the activity of nearby karstic springs and streamlets originated from Pangaeon Mountain.

\section{Conclusions}

During the combustion of the Philippi peat, Ag, As, $\mathrm{Ba}, \mathrm{Be}, \mathrm{Cd}, \mathrm{Ge}, \mathrm{Hf}, \mathrm{Ho}, \mathrm{Mo}, \mathrm{Sc}, \mathrm{Sn}, \mathrm{Sr}, \mathrm{Ta}, \mathrm{Tb}$, and $\mathrm{Zn}$ proved to be the most mobile elements. The scattered mobility and partition of the trace elements across the samples are related to the geological and climatic conditions that influenced peat accumulation. The latter should be traced and mapped both in the vertical and lateral directions. Mapping of vertical and lateral variations in peat mineralogy and trace el ement composition allow one to obtain a more comprehensive view of the potential environmental effects such as groundwater contamination and hazardous air pollutant emissions, from the use of the Philippi peat as fuel.

Acknowledgment. This work was funded through the Greek-Spanish Bilateral Agreement for Scientific Research, which is gratefully acknowledged. An anonymous reviewer is gratefully acknowl edged for valuable suggestions that improved this paper.

EF 0200673 